\title{
Anti-Apartheid, Anti-Capitalism, and Anti-Imperialism: Liberation in South Africa?
}

The first Mandela was Jesus Christ. The Second was Nelson Rolihlahla Mandela. The third Nelson Mandela are the poor people of the world.

(S'bu Zikode, a leader of Abahlali baseMjondolo, the South African shack dwellers movement, quoted in Gibson 2006: 12)

Ness, Immanuel and Cope, Zac (editors) The Palgrave Encyclopedia of Imperialism and AntiImperialism New York: Palgrave Macmillan

\section{Introduction}

On 16 August 2012, heavily armed South African police ambushed and hunted down striking mine workers. They killed 34 miners, wounded another 78 and then arrested a further 177 strikers, incredibly charging them with murder. The miners worked at Marikana platinum mine owned by British company Lonmin, and were on strike for a living wage (Alexander et al. 2012). A tough hand had been called for by Cyril Ramaphosa, once a leader of the miners union, but now a multimillionaire and a Lonmin shareholder. The Marikana Massacre was a turning point, demonstrating beyond reasonable doubt that the ANC Government sides with big business against the workers.

Little over a year later, on 5 December 2013, Nelson Rolihlahla Mandela, the personification of dignified resistance to apartheid, and his country's first democratically elected president, died aged 94 years. The world's media recalled Mandela's role in leading the ANC liberation struggle, his 27 years in prison, and dwelt at length on the generosity of his spirit in the reconciliation with his former oppressors. Honouring a great man whom they had spent decades fighting was not simple hypocrisy; the international bourgeoisie let out a detectable collective sigh of relief that matters had not turned out worse.

To bracket the Marikana Massacre with Mandela's passing captures the deep ambiguities of contemporary South Africa, where apartheid has gone but capitalism seems as entrenched as ever. What had the liberation struggled achieved? Where did it go wrong? What still needs to be done? Those who see Mandela as untouchable locate the problem as a post-Mandela degeneration in presidents Mbeki and Zuma. Others see the deal that Mandela struck as the source of the problem, delivering an end to apartheid but on terms that guaranteed private ownership of the means of production. In the early 1990s, the ANC leaders certainly felt faced with a stark choice between a pragmatic peace and revolutionary war. Was the ANC's strategy wrong, or was it just as far as it could get given the balance of forces?

This essay takes the long view on these questions, outlining a series of critical debates concerning the relations between apartheid, capitalism, and imperialism. We focus on the connections between theoretical perspectives and movement strategies, with special reference to the nexus between British imperialism and capitalism in South Africa. Our lens excludes as it magnifies; we do not cover vital related topics including especially the struggle experiences of the African masses, South Africa's occupation of Namibia, and wars against the Frontline States, the impact of the divestment movement led by African Americans, and the role of the US and international finance in apartheid's end game, all of which are needed for a rounded picture.

The theoretical perspectives considered are successively anti-imperialist, anti-apartheid, and anti-capitalist. The essay argues that a new synthesis of these perspectives is possible and necessary. The nub of the debate is the dominant, orthodox, communist strategy of transition summed up in the term 'national democratic revolution'. We will see 'national democratic revolution' had two distinct versions rooted, ultimately, in distinct class interests, and that the concept needs to be rescued from the pro-bourgeois, orthodox communist version. The essay concludes that South Africa today is a particular case of neo-colonial capitalism generating particular forms of resistance that involve fighting racism and imperialism on class terms. 


\section{South Africa and theories of imperialism}

The conquest and domination of African peoples in southern Africa feature in the classical Marxist theories of imperialism. Beyond the direct reportage and commentary by Hobson (1900; 1988/1902), the Marxists Hilferding (1981/1910), Luxemburg (2003/1913), and Lenin (1916a; 1916b) all sought to build this history into a wider theoretical explanation. Between them, these authors address economic, social, and political aspects of the relation between Britain and South Africa. In general, this literature treats the relation as an archetype of modern world imperialism. Moving from the abstract to the concrete, in this section we will ask what did these theorists of imperialism from middle and eastern Europe learn from South Africa?

Starting with the most strictly economic approach, Hilferding concentrates on the reorganisation of capital's corporate forms. He was involved in a simultaneous exposition and critique, a sustained dialogue between the categories of Marx's Capital and capitalism as it had evolved a generation later. Hilferding sets up a dialogue with Capital; especially Volume 3, Part 5 on the division of profits, which he seeks to extend. Although he does not entirely lose sight of production, Hilferding leaves the labour process in the background. In the foreground are changes in the forms of capital as value-in-circulation, the creation of capital markets, the socialisation of capital, futures markets, joint stock corporations, the stock exchange, and credit as capital that are still recognisable and of enormous significance today.

Hilferding fastens onto the significance of what Marx termed 'fictitious capital', defined as a property claim on future income (Hilferding 1981/1910: 597). He highlights that shares in joint stock companies are a form of fictitious capital, a capitalised claim on the future profits of the company, and so the turnover of these shares 'is not a turnover of capital, but a sale and purchase of titles to income' and that 'aside from the yield their price depends upon the rate of interest at which they are capitalized'; it is therefore 'misleading to regard the price of a share as an aliquot part of industrial capital' (111). When shares are issued and sold for money 'one part of this money constitutes the promoter's profit ... and drops out of circulation in this cycle. The other part is converted into productive capital and enters the cycle of industrial capital' (113). Hilferding's step forward is to identify the inversion of form, how the socialisation of industrial capital is mediated through finance, and that this actually further disguises the source of profits. This is relevant because companies offering shares in South African gold mines were being launched on the London stock market, thousands of miles away from the site of production, and gave both the London banks and financiers like Cecil Rhodes enormous windfall 'promoter profits'.

Hilferding claimed that his study of 'dividends as a distinct economic category' took the analysis of the corporation 'considerably beyond' Marx's 'brilliant sketch of the role of credit in capitalist production' (114-115). This opened the question that Lenin would make explicit: the character of changes in capitalism beyond those analysed by Marx. Marx had already perceived in the capitalist joint stock company 'a necessary point of transition towards the transformation of capital back into the property of the producers, though no longer as the private property of individual producers, but rather as their property as associated producers, as directly social property' (Marx 1981/1895: 568). For Marx, the socialisation of capital showed the real possibility of a mode of production controlled by the associated producers; that is, socialism. Without directly refuting Marx's optimism, Hilferding's analysis registered that the joint stock company had actually become the vehicle for imperialist surplus-profit. The potential for socialist transition that Marx foresaw in the form of socialised capital had turned in a reactionary direction. Hilferding highlighted the export of industrial capital in the production of raw materials, pointing out that price fluctuations and hence profit variability lead to a strong tendency to the formation of cartels in this sector. Capital investment in these new territories, he argued, 'turns towards branches of production which can be sure of sales on the world market'. 
Capitalist development in South Africa ... is quite independent of the capacity of the South African market, since the principal branch of production, the working of the gold mines, has a practically unlimited market for its product, and depends only upon the natural conditions for increasing the exploitation of the gold mines and the availability of an adequate work force. (Hilferding 1981/1910: 317)

Hilferding did not delve into the racial colonial processes involved in procuring 'an adequate work force', but he did mark a change in the role of certain colonies within capitalism as a whole, from commodity consumers to producers of surplus value.

Rosa Luxemburg gave a stirring critique of the racism and violence of colonial capitalism. Her The Accumulation of Capital has a chapter on capitalism's struggle against the peasant economy takes South Africa as the major example. Luxemburg charted the dispossession of the original African peoples by the Boer farmers, and then their ousting by the British mining interests. The history is excellent, but there is an issue with her theory. At its most general form, Luxemburg stated:

Imperialism is the political expression of the accumulation of capital in its competitive struggle for what remains still open of the non-capitalist environment. (2003/1913: 426)

While Luxemburg's framing is sensitive to the battles of first nations at the frontiers of expanding capitalism, it is incomplete as a theory of their incorporation as oppressed nations within the capitalist mode of production. She sees the mode of production of the conquered society as persisting in a subordinated relationship to the conquerors, rather than a new synthesis of extended capitalist social relations that also changes the conqueror's mode of production (for elaboration of this idea, see Higginbottom 2011). A form of Luxemburg's argument has been influential in Wolpe's articulation of modes of production approach (see below).

Whereas Luxemburg's theory of imperialism emphasised that capitalism inherently requires sources of value from societies external to it, Lenin's theory is of a capitalism that has been transformed in its expansion. As did Luxemburg, Lenin ascribed great significance to the Anglo-Boer War of 1899-1902, which he placed with the US war with Spain in 1898 as an historical turning point of global significance. In Imperialism the Highest Stage of Capitalism (1916a), Lenin argued that these two wars marked a new stage in which a handful of imperial powers fought each other in order to gain colonial possessions; that these wars served to redivide the world between them. Lenin acknowledged that he had learnt much from the 'social reformer' Hobson's 1902 work based primarily on South Africa, describing it as 'a very good and comprehensive description of the principal specific economic and political features of imperialism'. He saw those features most pronounced in Britain as a 'rentier society' enjoying 'super-profits', and the domination of finance that had sprung from the spectacular profits extracted from South Africa, India, the West Indies, and other colonies.

Most distinctive in Lenin's theory of imperialism is that it has a political side (imperialism as generalised and intensified national oppression) and an economic side (imperialism as monopoly capitalism, the domination of finance) which he did not have time to integrate with Marx's critical political-economy. In contrast to Hilferding's detailed extension of the categories of Volume 3 and Luxemburg's robust critique of Volume 2, Lenin's 'popular outline' on imperialism [(1916a)] does not reference back to Capital. He was more concerned to present the totality of contradictions, to connect the military conflict in Europe with the economics of imperialism. In this regard there is a greater theoretical leap with Lenin than with his contemporaries, and because not all the conceptual mediations were filled in, perhaps a leap of faith by Lenin that he had applied Marx's spirit of revolutionary dialectics to the new reality (Anderson 1995).

What Lenin did achieve was the filling out of his concept of modern imperialism as a new stage of capitalism to encompass a fresh look at social class relations. He was especially concerned to chart the social roots of 'opportunism' in Europe, the tendency to reconciliation with the ruling class even as it engaged in imperialist oppression and war. In the rich countries, the working class had 
become more differentiated, with an upper stratum merging with the petit bourgeoisie that was socially corrupted and bound to the benefits of imperialism, a 'labour aristocracy' that for material as well as ideological reasons backed its own state in the war. Although imperialism had created a split in the working class, resistance had at the same time created the possibility for unity of workers in oppressor and oppressed nations on the political basis of support for national self-determination. In the poor countries, specifically the colonised nations, national liberation movements were agents of rebellion and revolution that the poorer strata of workers in the rich countries should unite with as allies against their own imperialist state and its labour aristocratic defenders (Lenin 1916b).

Another aspect of Lenin's analysis of imperialism was the class relations within the oppressed nation and the social basis of their distinct political objectives. This aspect was quite undeveloped in Lenin's initial analysis, which was challenged by Indian M.N. Roy in debates at the second congress of the Communist International. Together they developed a position that recognised the distinct experiences and role of the working class in the oppressed nation (Lenin 1920; Roy 1922).

The recognition that capitalism had created structural divisions and splits within the working class internationally resonated strongly in South Africa, from where, quoting a contemporary observer Mr Bryce, Hobson reported an 'absolute social cleavage between blacks and whites':

The artisans who today come from Europe adopt the habits of the country in a few weeks or months ... the Cornish or Australian miner directs the excavation of the seam and fixes the fuse which explodes the dynamite, but the work with the pick axe is done by the Kaffir.

(Hobson 1900: 293-294)

Half a century later, and this 'absolute social cleavage between blacks and whites' would be pushed yet further.

\section{Debating the struggle against apartheid}

The apartheid system was introduced in 1948 and lasted until South Africa's first non-racial elections in 1994. Apartheid was intense racism across all spheres of life, justified as a programme of 'separate development' for racially identified groups.

After the Second World War, the increasingly urbanised African workforce was employed in manufacturing (men), services and domestic labour (women), as well as on the mines and farms. The entire African population was denied citizenship of South Africa; instead, Africans were designated citizens of ten remote, impoverished, ethnicised Bantustan homeland states to where around 4 million would be forcibly removed as 'surplus people'. Black Africans constituted over 70 per cent of the population but could hold only 13 per cent of the land. The barrage included racial classification of 'Indians' and 'Coloureds' as well. Apartheid's segregation laws meant that all political and economic power was reserved for 'Whites', only 15 per cent of the population (IDAF 1983; Mamdani 1996; Platzky and Walker 1985).

The racist assault called forth a defiant response from the oppressed majority. The ANC Youth League played a leading part in a Defiance Campaign that built up over the 1950s, the era that gave birth to the Freedom Charter whose story is told in Nelson Mandela's autobiography and rightly celebrated in most accounts (Mandela 1994). The Charter remains for many the foundational antiapartheid document. 'The People Shall Govern! ... All National Groups Shall have Equal Rights! it declared. Moreover, its economic demands centred on sharing the country's wealth: 'the mineral wealth beneath the soil, the banks, and monopoly industry shall be transferred to the ownership of the people as a whole ... and all the land redivided amongst those who work it, to banish famine and land hunger' (ANC 1955). The ANC formed a multi-racial coalition around the Charter, including the Indian Congress, the Coloured People's Congress, the (unmarked white) Congress of Democrats, the trade unions, the South African Communist Party (SACP) and so on, designated 'the Congress Alliance'. 
Less well known, but of lasting significance, is the emergence of the Pan Africanist Congress (PAC) at this time. The 'Africanist' PAC was against white supremacy, it had split from the 'charterist' ANC on several related grounds including disagreement with the excessive influence of white communists in its leadership. The PAC pointed out that different national groups were not the same; Africans were the absolute majority and that to put the exploiting, European white minority on the same footing as Africans as a national group was to reproduce white privilege within the Congress Alliance in the name of equality. The PAC identified their commonality with other African liberation struggles, and emphasised the land question, in which regard the PAC saw South Africa as a case of settler colonialism. See especially the PAC's leader Robert Mangaliso Sobukwe's inaugural speech for a clear explanation of these themes (Sobukwe 1959). In practice, the PAC showed a stronger commitment to mass initiative, but weaker organisational infrastructure than the ANC working with the Communist Party. For example, the 1960 protest at Sharpeville against the pass laws, brutally shot down by the police, was in fact called by the PAC. As both liberation organisations turned to guerrilla armed struggle in the wake of the Sharpeville Massacre they were both banned, their activists hunted down, killed, tortured, and imprisoned. The racist regime even passed a special law allowing it to imprison Sobukwe, as well as Mandela and ANC comrades (Lodge 1983; Pogrund 1990).

\section{The SACP version of the national democratic revolution}

So it was in the immediate context of the Communist Party's rivalry with Pan-Africanism that its version of the national democratic revolution crystallised in the early 1960s. The SACP's forerunner, the Communist Party of South Africa (CPSA) founded in 1921, had originally been oriented to the white workers and supported their strike in 1922, infamously behind the racist slogan 'Workers of the world, unite and fight for a white South Africa!' The party then shifted attention to the black majority of workers, although the Executive Committee of the Communist International still found it necessary to admonish its South African comrades: "the CP cannot confine itself to the general slogan of "Let there be no whites and no blacks." The CP must stand the revolutionary importance of the national and agrarian questions'. It urged the party to invite black workers 'without delay into much more active leadership' (ECCI 1928).

In stating its political strategy 30 years later, the Soviet-inclined 'Marxist-Leninist' SACP still found the use of Lenin's thought to be ideologically central, and so we turn now to that legacy. In his Two Tactics booklet written in 1905, Lenin had analysed that there needed to be two revolutions in Russia: first, a democratic revolution to sweep away the Tsarist feudal dictatorship and bring in a democratic republic; then a socialist revolution to get rid of capitalism. Lenin argued an energetic interventionist tactic in the first, democratic revolution, so that it be pushed to its fullest limit, towards a 'revolutionary-democratic dictatorship of the proletariat and the peasantry'; and that this would be against the bourgeoisie whose instincts were to compromise, to do a deal with the Tsar and the landlord class. In this way the ground would be prepared for passing on to the socialist revolution. The actual course of the revolution confirmed Lenin's general orientation, albeit in a way that was unexpected due to the realignments of the First World War which saw the Russian bourgeoisie turn ever more decisively against the mass of workers and peasants.

The struggle for independence was of course a long-standing issue for oppressed peoples in countries occupied by European colonialism, that was posed afresh by the national movements in the 20 th century. The idea of the national democratic revolution was widely debated in the early years of the Communist International including, as we have indicated, with reference to strategy in South Africa. It was from these antecedents that the SACP constructed its own version of the national democratic revolution. In 1962, the SACP adopted the thesis of 'colonialism of a special type' arguing that the

'the combination of the worst features both of imperialism and of colonialism with a single national frontier', maintained in the interests of all whites, but particularly the monopolies 
which 'are the real power'. In this 'white colonialist system' the task of the Communist Party 'is to lead the fight for the national liberation of the non-white people, and for the victory of the democratic revolution'. (Davies et al 1984b: 291)

From this perspective, the party gave its 'unqualified support' to the Freedom Charter, arguing that, although not itself 'a programme for socialism', nonetheless:

its aims will answer the pressing and immediate needs of the people and lay the indispensable basis for the advance of our country along non-capitalist lines to a socialist and communist future. (SACP 1962)

This ambiguous formulation was to leave many questions open as to how the democratic revolution would connect 'along non-capitalist lines' to a socialist future.

Several crucial points were overlooked in the SACP's rendering of Lenin. First, the whole point of Two Tactics was that the working class should ally with the peasantry to together play the leading role in the democratic revolution against feudalism; Lenin warned that the Russian bourgeoisie would vacillate and seek to make a deal short of full democracy. Second, while the political goal of the democratic revolution was to gain a republic, as that afforded the best grounds for working-class organisation to flourish, its social purpose must be to destroy private ownership in the land. Learning from the experience of peasant revolts against the landlord class, Lenin (1907) went on to emphasise that the land should be nationalised to complete the democratic revolution. As circumstances changed again in the First World War, he added "nationalisation of the land is not only the "last word" of the bourgeois revolution, but also a step towards socialism' (Lenin 1917). Third, while Lenin retained an analytical distinction between the democratic revolution and socialist revolution, their relationship changed in practice. As the class struggle changed reality, Lenin changed his conceptualisation. In his later understanding, he presented them more and more as phases in a continuous, complex revolutionary process. This applies to the actuality of the Russian revolution itself as well as to anti-colonial struggles; throughout, there was a sense of revolutionary dialectics on how the two could be connected to the best advantage of the working class.

How then would the national democratic revolution to get rid of apartheid be prosecuted to the best advantage of the African working class? The SACP's 'colonialism of a special type' has drawn one line of criticism from Trotskyism on the grounds that it justified armed struggle, and turned away from the specific mission of the working class (Callinicos 1988: 61-72). For Hirson, the SACP's 'two stage theory' of revolution 'became the hallmark of Stalinism in South Africa' (1992: 48). The Trotskyists' critique of 'two stages' (actually two revolutions in the SACP interpretation) and their preferred 'permanent revolution' thesis based on (Trotsky 1906) suffers from two problems (both of which were forms of abstraction). First, it was abstract politically: there was an urgent need for a democratic national liberation movement uniting forces to end racist apartheid, including by violent armed struggle as required. Second, the critique was theoretically schematic: it harked back historically but was disconnected from an actualised political economy of current realities. The left critique of the 'Stalinist' SACP needed to be grounded in the concrete debate about apartheid's connection with capitalism and imperialism, which was about to surface.

SACP theorist Brian Bunting's book The Rise of the South African Reich clarified the direction the party had taken: it sought liberalism as an ally. Bunting identified two wings of Afrikaner political leadership in response to the British state-building strategy that forged the Union of South Africa in 1910. The orientation of 'Milnerism' was the offer of an alliance between the predominantly British mining magnates and Afrikaner settler farmers as the dominant class. Generals Smuts and Botha were for conciliation with the British ${ }_{2}$ Hertzog was for a separate path for Afrikaners (Bunting 1964: 2223). Bunting emphasised that Hertzog's Nationalist Party supported Hitler in the 1930s. If the point was not sufficiently clear, his book was published with swastikas on its cover. The Afrikaner 'Nats' stood for wit baaskap in the 1948 election. Bunting translates baaskap literally as 'mastership': Charles Feinstein (2005: 161) translates wit baaskap more meaningfully as 'white domination'. The 
Nationalists gained 70 out of the 150 seats and, as the biggest single party, formed the government that implemented a series of measures to stop all forms of integration; and to enforce racial exclusion of the black majority, brought in apartheid, otherwise known as 'separate development'. Bunting portrayed these as 'South Africa's Nuremberg Laws'. He framed apartheid as a policy that was the product of Afrikaner nationalism's convergence with Nazi ideology. This in turn implied a 'popular front' opposition strategy that involved uniting with all possible forces, in particular with British liberal democratic capitalism, against the greater evil. This view of apartheid was widely shared internationally at the time, and in that sense is not exceptional. The significance was that Bunting was an SACP guiding light, yet his analysis suppressed entirely the legacy of Marxist theorising South Africa in its relation with capitalism and imperialism.

In many respects, the strengths and weaknesses of the final outcome of the anti-apartheid struggle were already present in Bunting's analysis. The persistence of this line of thought, despite its obvious one-sidedness, can only be because it corresponds to certain class interests.

\section{Apartheid as a stage of racial capitalism}

In the 1970s there was a flourishing of Marxist scholarship, mostly written in exile, influenced by ideas of the 'New Left', and motivated by the liberation of Angola and Mozambique from Portuguese colonialism and the recovery of struggles inside South Africa, most especially after the Soweto Uprising in 1976.

The South Africa Connection by First, Steele and Gurney on Western investment in apartheid is a classic that deserves to be republished. There was a brief dip, then foreign investment surged after the Sharpeville Massacre. Two-thirds of the investment came from Britain, such that 'it is hard to imagine how some sectors, like banking ... would keep going without British backing' (First et al. 1973: 9). The explanation for the investment surge was simple: the spectacular returns to investors 'is exactly what apartheid is all about' (15). First et al. recognised specifically Afrikaner prejudices but, they argued, the difficulty with this description of apartheid:

as the result of a clash between two aggressive nationalisms - African and Afrikaner does not explain, for one thing, why and how apartheid grew so naturally and effortlessly out of the state policies pursued, not in the Boer Republics but in the British ones, when South Africa was a colony run from Whitehall. (16)

Although they do not critique him directly, First et al. were challenging Bunting's analysis. The emphasis in this new approach was on apartheid as the latest stage of capitalism in South Africa, as well as a set of ethnic/nationalist policies. The starting point of the revisionist school of analysis was the relation between class and race in the formation of a modern, industrial 'racial capitalism'. Harold Wolpe (1972) and Martin Legassick (1974) were founding contributors to this new school, both of whom focused on the system of migrant African labour for the gold fields from 1890 onwards. Frederick Johnstone (1976) and Bernard Magubane (1979) wrestled with theorising the role of British imperialism as colonial capitalism. What is distinctive here is the concentration on the establishment of the corporate mining system as the foundation of modern South Africa, historically prior to apartheid as such.

The new analyses engendered a debate with liberalism, which is reviewed in (Alexander 2003). Could big business become a force against apartheid? Could, as the liberals claimed, foreign investment be portrayed as at all beneficial for the African working class?

The general point that the new Marxists argued is that, contrary to the liberal claim that capitalist growth 'would in the long run undermine the racial structure of apartheid', it was actually accompanied by 'ever increasing repression' (Legassick and Innes 1977: 437). Liberal author Merle Lipton's response argued that, in absolute and relative terms, the condition of African labour was improving. 'If important groups of capitalists are increasingly tending not to support apartheid, then 
this makes possible the option of cooperation with them' (Lipton 1979: 75). Consequentially, for Lipton, a 'constructive engagement' with big business to end apartheid was viable.

Apart from the empirical grounds of the dispute, and the political consequences, of which more later, there was a theoretical Achilles heel in the Marxist response to the liberals. Although approaching the issue in historical materialist terms, most of the new Marxists baulked at a concept of greater exploitation which was required to anchor their argument, to connect racial capitalism with imperialism theoretically.

\section{Debate over the rate of exploitation}

Infrequently cited but worth close attention is the critique of Wolpe by Michael Williams (1975), who applied Marx's theory of money to stress the particularity of gold production in South Africa. Wolpe and Williams made a serious attempt to use the concepts of Marx's Capital in their analysis of the specific social relations constituting South African capitalism. Wolpe highlighted that reproduction of migrant labour-power in pre-capitalist societies with low money costs, allowing mining capital to pay low wages to African workers. South Africa emerged as a social formation in which the capitalist mode of production draws value from pre-capitalist modes. Echoing Luxemburg, Wolpe interpreted this relation of exploitation relying on reproduction outside capitalism as the continuation of Marx's 'primitive accumulation'

Williams's intent was to critique both Wolpe and the SACP thesis. He fastened on the particularities of value production by African labour in the gold fields. Williams replaced Wolpe's outer contradiction with pre-capitalist modes as the source of extra surplus-value with an inner contradiction peculiar to the capitalist production of gold as the money commodity. Gold mining capitalists had a privileged position that allowed them to draw surplus profits: 'the gold mining industry is in a unique position to reap the benefits of exploitation directly in accordance with the quantity of immediate labour it employs' (Williams 1975: 23). This draws on Marx's theory of absolute rent, and needed further development using the theory of differential rent, but which nonetheless was a big step forward. For a discussion of Williams and Wolpe which argues that the 'articulation of modes of production' is better theorised as a re-articulation of the capitalist mode of production itself, in which race is internalised as part of the capital-labour relation, see (Higginbottom 2011). In place of the notion of colonialism of a special type to explain South Africa's exceptionalism, Williams argued in effect for a fuller concept of capitalism of a special type. With the idea of 'archaic surplus-value' he came close to the categorical breakthrough achieved by Marini in Latin America, with the concept of the super-exploitation of labour, see (Latimer 2014).

In a paper published by the British Anti-Apartheid Movement, Good and Williams (1976) reached a high point from which to take the theoretical debate forward. The purpose was to convince British workers that their solidarity would serve a common interest. What was innovative in their argument was the application of Marx's explanation of the declining rate of profit to the problem, in relatively popular form. They opened their discussion in similar vein to Legassick (1976: 437), who argued that although African workers were paid significantly less than workers in Britain, British workers were nonetheless in a technical sense actually more exploited because they were more productive, and hence received relatively less for their labour. This is more than a view, but rather a widely held ontological assumption of Trotskyism and north-centric Marxism in general. In line with this thinking, Good and Williams offered a worked example to demonstrate the difference in value relations between an 'advanced country' (such as Britain) and a 'neo-colony' (such as South Africa). In their example, productive technique and hence the ratio of capital invested to labour is much higher in the advanced country, thus:

Let $4: 1$ be the capital-labour ratio in the advanced capitalist country and 1:4 in the neocolony; and let 100 per cent be the rate of exploitation in the former and 50 per cent in the latter' (Good and Williams 1976: 8). 
The analysis was bounded by these two assumptions; but were they correct?

On the first assumption, Good and Williams's data showed that in 1970 the gross fixed capital formation per manufacturing worker in South Africa was just marginally below that in the UK. But investment in South Africa was increasing faster, so, by 1973, fixed capital per worker was slightly higher in South Africa than in the UK. Insofar as gross fixed capital formation per worker is a reasonable proxy for the mechanisation that led to greater productivity, what Marx termed the technical composition of capital (1976/1867: 762), the UK and South Africa manufacturing averages were roughly equivalent. A Land Rover production line in Pretoria was in fact technically quite similar to one in Solihull, and the workers were similarly productive.

The second assumption of the illustrative example concerned the rate of exploitation, yet this was precisely what had to be investigated rather than assumed. Marx explained that within the capitalist mode of production the rate of exploitation of labour is the same as the ratio of surplus value to variable capital, which he called the rate of surplus value. The rate of exploitation of the workers is the surplus value they produce (s) divided by variable capital (v) exchanged in wages to purchase their labour power (1976/1867: ch. 11). The ratios of 100 per cent rate of exploitation in the advanced country and 50 per cent in the neo-colony are similar to the ones given by Marx, in a questionable example comparing a European country 'where the rate of surplus value might be 100 per cent' and 'in an Asian country it might be 25 per cent' (Marx 1981/1895: 249), which he did not justify empirically, and which bears no relation to the international production relations of contemporary capitalism, but which has been clung onto as a crutch by subsequent north-centric Marxists. Good and Williams assembled data that showed there could not possibly be a lower rate of exploitation in South Africa than in the UK, because on the basis of a similar technical composition investors were able to make a significantly higher rate of profit. 'We can only conclude that the relatively high rate of profit in South Africa is more a function of the high rate of exploitation than of low capital-labour ratios' (Good and Williams 1976: 10). The investigation obliged Good and Williams to move beyond their initial assumptions and conclude that the rate of exploitation in South Africa was higher. When we add here that white labour was remunerated on average nine times more than African workers (Martin 2013: 26), and that by this time there were few white workers, rather white supervisors, this higher average rate of exploitation was entirely due to the drastically lower wages paid to the African workers for the same value produced.

We have arrived at a vital point for the political economy of apartheid, capitalism, and imperialism: the rate of exploitation considered quantitatively to demonstrate the material 'cleavage between black and white'. To illustrate, gold mining in South Africa publishes industry figures. This allows us to estimate the degree of exploitation of African gold-mine workers over decades. Selecting the same year that Good and Williams studied (i.e. 1970), the ore milled per worker was 193 metric tons; the average working revenue was R11.24, the working costs R7.34 and the working profit R3.90 per ton. In 1971, the average annual African wage was R209, at 1970 prices. Assuming the 1970 annual wage was also R209, the average wage cost was R209/193, that is R1.08, per ton (Feinstein 2005: 170; Lipset Lipton 1986: 410). Assuming that working profit is realised surplus value, and wage cost stands for variable capital, on these figures the gold-mining industry average rate of exploitation of African labour was R3.90/1.08 (s/v), or 361 per cent, nearly four times higher than the 100 per cent rate typically cited by Marx. Rather than, as Marx often observed, workers toiling half the working day for themselves and half for the capitalist, the African workers wages were the equivalent of less than a quarter of their labour time, with nearly four-fifths of their time going to the capitalist.

The above analysis corresponds with solidarity initiatives that some trade unionists in Britain the UK, such as the British Leyland workers, were taking against their own bosses (Luckhardt and Wall 1980: 481-483). On theoretical terrain, it fills a gap left by Hilferding, who viewed the international class relation from its European end, where the benefit to finance was apparent. The promoter's profit made in the launch of new mining companies and income from shares as fictitious capital had, eventually, to come from somewhere. What underpinned the new generation of joint stock 
companies and other forms of finance capital was at the other end of the relation, fundamentally the system of cheap labour, or super-exploitation of African workers, as the source of the expected surplus-profits (in this case identical to the super-profits in Lenin's terminology).

\section{The history of imperialism and racial capitalism}

The relation of imperialist super-exploitation is the axis around which capitalism in South Africa was built, and which buoyed up the monetary system of British colonialism, extending its life. Within two decades of the initial production on the Rand in the early 1890s, the gold industry employed a quarter of a million African workers at any time, with several times more than that number rotating through the migrant system. The British prosecuted the Second Boer War to wrest control of the Rand from the Afrikaner farmers, who themselves had dispossessed the Africans two generations before. Victorious Lord Milne inaugurated a regime tailored to the needs of mining capital: land laws, the colour bar, and pass controls (Callinicos 1981). The African National Congress came together in 1912, just two years after the birth of the South Africa Union, to protest 'the repression of all blacks in every conceivable form' (Meli 1988: 34).

Around two-thirds of the mine labour force came from outside the borders of the Union (Wilson 1972). In their first two decades, the Johannesburg mining houses were mostly financed from London, with some capital from Germany and France. Milne's project was foundational, shaping the contours of the state as a functioning apparatus of racial repression, and it situated South Africa's location in international political-economic relations. African labour was pulled in from neighbouring colonies, while profits flowed out to London. London moreover consolidated its control over the world's biggest source of gold. Gold bullion boosted the value of pound sterling and the City of London as a financial centre, and with that extended Britain's imperial privilege (Ally 1994). Once they had secured the Union, the British pursued rapprochement with the Afrikaners to secure internal political stability through white supremacy, in exchange for a share in the spoils. This power shift is seen as one of the 'systemic periods' in South African history that would transition again into apartheid in 1948 (Terrebalanche 2002).

A distinctly South African mining monopoly capital emerged when Ernest Oppenheimer formed the Anglo American Corporation in 1917. Using capital investments mostly from the US, Oppenheimer set about bringing the diamond and gold industries under the sway of centralised holding companies. The story is well told in Lanning (1979), and the dedicated book-length study by Innes (1984). These authors point out that underlying Oppenheimer's financial wizardry was an inherent tendency towards monopoly characteristic of gold production. As identified by Williams (1975), insofar as gold is the money commodity, the universal equivalent exchangeable with every other form of abstract human labour, capitalist gold producers have an unlimited demand for their product. Any increase in productivity, reducing production costs and expanding volume, increases profits without undercutting the 'price' of other gold producing capitals. This gave rise to a unique attenuation of competition in certain aspects. The gold mining capitalists of the early Rand were united in their determination to keep labour costs down through industry-wide 'maximum wage agreements', and they had a mutual interest in sharing knowledge on production techniques and output data. Corporate organisation passed quickly from hundreds of individual joint stock companies to just six financial groups that switched capital around a portfolio of gold mines according to their performance (Innes 1984: 55). Monopoly over the diamond industry started at the sales end, a cartel limiting sales to keep the price up. Oppenheimer's innovation was to build on these tendencies and take them to another level. He centralised existing mining corporations into a single conglomerate that rapidly rose to pre-eminence in South Africa, and beyond that into sub-Saharan Africa.

On its internal projection, Anglo American opened up mine production in the Orange Free State after the Second World War, requiring increased investment in plant and machinery to cope with the mines' extreme depth. The company concentrated its portfolio on the more profitable mines, and 
emerged as a 'dove' within the Chamber of Mines, lobbying for an increase in black wages that would reduce its reliance on foreign labour, and which it was in the best position to afford. Anglo's intention was not to get rid of the colour bar but to reposition it. The corporation's reforming pressure was within narrow limits defined by self-interest, and in any case could only ameliorate the growing gulf between white and black as captured in their earnings ratio, which had risen from 12 times in 1946 to over 20 times in 1969 (Lanning 1979: 156).

The external projection of the Oppenheimer empire is documented by Lanning and Kwame Nkrumah. Nkrumah argues that imperialism entered a new stage of neo-colonialism after the Second World War. He sees the essence of neo-colonialism being that although the subordinate state 'is, in theory, independent and has all the outward trappings of international sovereignty. In reality its economic system and thus its political policy is directed from outside' (Nkrumah 2002/1965 ix). Outside direction is targeted at the profitable extraction of Africa's mineral resources. In this regard, Nkrumah showed South Africa in a double relation with the rest of Africa. On the one hand, 'the whole of the economy is geared to the interests of the foreign capital that dominates it' (12) and, on the other hand, white South Africa's mining giant had spread neo-colonial tentacles of its own across Africa. Oppenheimer's De Beers diamond group drew profits from Sierra Leone, the Congo, Tanganyika, Angola, and South West Africa (today Namibia); and Anglo American subsidiaries mined in Rhodesia (today Zimbabwe) and Zambia.

\section{Neo-colonialism and Black Consciousness}

What is striking in Nkrumah's account is the leading of role of mining corporations alongside Finance as the principal vehicles of Africa's continuing neo-colonial domination. In his analysis, the main contradiction is between externally based capital and internally based democracy. This view is deepened by class analysis of neo-colonialism that confronts the voluntary alignment by an aspiring African middle class, choosing to align itself with the interests of the corporations and imperialism. Fanon (2000/1963) and Cabral (1966) analysed the class aspect of neo-colonialism in its subjective and objective dimensions. They warned against and fought against the neo-colonial alliance as an outcome of the liberation struggle (Saul 2012).

Fanon's mode of thought had its correlate in racist South Africa, Black Consciousness. Writing under the pseudonym 'Frank Talk', Steve Biko urged his fellow blacks to realise that 'the most potent weapon in the hands of the oppressor is the mind of the oppressed' (2002/1978: 68). The government banned Biko in 1973 and made it illegal to quote his words, and yet his thought contributed to a new generation of struggle, the workers revolt in the early 1970s, and most especially the school students' rejection of Afrikaans as the language of their education that animated the Soweto Uprising. Biko was assassinated in 1977, and the next year his comrades formed the Azanian People's Organisation (AZAPO).

Under the pseudonym 'No Sizwe', Neville Alexander wrote One Azania, One Nation to dissect the Nationalist Party apartheid ideology in the construction of groupings of people through the prism of 'race', with the Bantustans as the lynchpin. Alexander brought a fresh perspective into the debate. He argued that understandings of race held by different currents 'tend to become tied to the related question of which class should lead the national liberation movement' (Alexander 1979: 98). He identified three conceptions of national liberation in South Africa. The first, which had been advocated in the ECCI 1928 memo, was for an independent native republic. The second conception was 'the democratisation of the polity within the existing capitalist framework ... that the black people should be integrated in the existing system by being given formal political equality' (285286), as advocated by the SACP/ANC alliance (whether this is a fair characterisation of the Freedom Charter is part of the debate). Alexander advocated a third conception: the unity of the non-Europeans to overcome the white bourgeois class strategy of division and fragmentation in which 'the nation ... 
consists of all the people who are prepared to throw off the yoke of capitalist exploitation and racist oppression' (290). 'Azania' was the term adopted to relay the idea of one nation of all the oppressed.

Black Consciousness drew in some measure from the transition that took place amongst African Americans from civil rights to radical nationalism. The debates over how to defeat racism arose in different contexts, yet began to overlap.

\section{Debating solidarity strategy}

Another aspect of the debates internal to the movements, that indeed throws light on them, is the debate on international solidarity strategy.

As we have seen, First el al. (1973) had pointed out the vital importance of the South Africa connection for sustaining the imperialist character of British capitalism, with 10 per cent of its direct investments and 13 per cent of its foreign profits worldwide (1973: 334). To the economic we should add military collaboration, on which Labour Governments in the 1940s, 1960s and 1970s had an appalling record, especially with regard to purchasing uranium from South Africa and illegally occupied Namibia (Brockway 1975; Moorsom 1982). Far from banning the nuclear bomb, Labour had connived with apartheid to make it. This raised again Lenin's analysis of the labour aristocracy, a privileged layer expressed through the official labour movement that would block effective moves to undermine the very relation from which it drew its privilege (Yaffe 1976).

The debate over solidarity strategy has been resurrected in recent publications. Fieldhouse (2005) offers a history of the British Anti-Apartheid Movement (AAM) as a pressure group. Thörn (2006) conceives of 'anti-apartheid' as a social movement, a successful campaign that he presents as a model for transnational action. Both works downplay the degree of British involvement with apartheid; that is, they express the AAM's standpoint in the debates of the time, drawing at least one sharp review (Brickley 2005). There is an ongoing research project that investigates the views and actions of participants in what became known as the militant wing of anti-apartheid and which offered a distinct strategy, the City of London Anti-Apartheid Group (Brown and Yaffe 2014). It is timely to review the debate, not least for any lessons that may be drawn for future international solidarity campaigns.

Even by its own terms of maximising unity against apartheid, the AAM made a strategic error. In practice, its mobilisation against British collaboration with apartheid was constrained to what was acceptable to the official trade unions and Labour Party in Britain, and since Labour had in government itself collaborated fully with apartheid, the extent of AAM action was generally no more than formal lobbying. In fact, most purposeful initiatives to break the routine of collaboration came from outside the official AAM, the clearest indicator being the Stop the Seventy Tour (Hain 1971: 120-125).

The question of unity needs to be considered dialectically in relation to the struggle. The right point of unity in the struggle cannot be defined in the abstract, but in the concrete (Cabral 1989). It was the masses in South Africa, in Namibia, their liberation movements and the Frontline States who were fighting apartheid directly, and their struggle was the primary motor for the entire movement. The solidarity movement was a support base that could only fight apartheid indirectly, a secondary but nonetheless important role, and to do that effectively it had to have its own clear strategy. In its close co-operation with the SACP and the ANC, the official AAM strategy confused roles whereas there was a need to distinguish between them. If the solidarity movement had a single issue to concentrate on, it was to isolate apartheid, to weaken it from without and that meant fighting collaboration between its own establishment and the apartheid regime, to work for sanctions. To do otherwise would be to renege on its specific responsibility. The greater the collaboration, as in the case of imperialist countries such as Britain and the US, the more this was so. In fighting British collaboration 
with apartheid, solidarity forces in Britain were providing the most effective contribution they could to fighting apartheid (Brickley et al. 1985).

A further problem became ever more evident. The mobilising activity of the City of London Anti-Apartheid Group came across a second constraint, that given its position as a solidarity campaign was at first difficult to accept and later even harder to comment on publicly. Despite their antiimperialist rhetoric, the SACP and ANC were in practice opposed to an anti-imperialist campaign that risked alienating allies in the Labour Party and other sectors of the British establishment. They were closely tied to the AAM, its orientation was theirs too. Once this was realised, the sectarianism of the ANC towards solidarity with other currents arising in South Africa, its tendency to put itself forward as the sole representative, to discourage direct trade-union solidarity links, and to court only socialdemocratic support all fell into a new light.

In the meantime the struggle had taken a leap forward. The racist regime was confronting manifold political and economic challenges that led it to instigate a phoney reform programme of controlled internal changes (Price,1991). The combination of co-option and repression failed to stem the upsurge in popular protest. The United Democratic Front (UDF) was formed in 1983 to oppose a stooge 'tricameral parliament', a national organisation with an international audience. The UDF was an internal correlate of the ANC, linking it to the mass upsurge on the programme of anti-apartheid unity. Murray (1987) relates the widespread eruptions of popular revolt, 'stayaway' strikes, civic protests, and the broadening of political struggle in the mid-1980s. Every time the regime turned the screw, the resistance grew. The Vaal Uprising in 1984 was an explosion of working-class rebellion. Even the State of Emergency in 1985 could not halt the protest spreading nationwide. To his lasting credit, Mandela steadfastly refused to countenance any deal short of one person one vote, even at the expense of staying in prison. Towards the end of the decade the regime was reaching an impasse, every move it made thwarted by the preparedness for insurrection, not by the increasingly concerned ANC/UDF leadership but from grass-roots forces, whether UDF aligned or not. It was doubtful they could be held back, raising the possibility of an internal people's war to match the wars going on outside South Africa's borders.

Ten years of Kissinger's policy of 'constructive engagement' had failed to rescue Pretoria, cracks were appearing in the alliance of international forces protecting the regime. The State of Emergency had the unintended consequence of unsettling international lenders, who from the credit crisis of 1985 began to look for an exit strategy (Ovenden and Cole 1989: ch. 4). Sanctions had really begun to bite (Commonwealth Committee 1989; Orkin 1989). South Africa's 'total strategy' security doctrine meant saturation terror in Namibia, and took an awful and devastating toll on the adjoining populations of Mozambique, Angola and the other frontline states (Hanlon 1986). At the close of several months of fighting, at the Battle of Cuito Cuanavale, in early 1988, Cuban-piloted planes and tanks helped Angola's MPLA Government defeat the invading South African forces. After having inflicted tens of thousands of African casualties, hundreds of white South Africans were now also being killed. Not only had South Africa's invasion of Angola been repulsed, its ability to maintain the occupation of Namibia without further morale-sapping losses was doubtful. Forced back on its external front, and facing internal insurrection, the racist minority regime's capacity to sustain total warfare had been tested to breaking point. The apartheid state could no longer guarantee capital accumulation and racial domination, the question of reform or revolution had truly arrived. On the side of white supremacy, P.W. Botha's resignation in 1989 cleared the way for new president F.W. de Klerk to address the previously unthinkable: steps towards a negotiated non-racial settlement (Price 1991: 11).

\section{Beyond apartheid: managed transition}

By the mid-1980s, the racist regime had entered into a prolonged 'organic crisis' (Saul 1986). As reflected in publications such as Work in Progress, Transformation, South Africa Labour Bulletin and 
South African Review the debate on the opposition side had returned with fresh immediacy to the question of political power and what would happen beyond apartheid.

\section{Two class interpretations of the national democratic revolution}

Under the pressure of an intensifying class struggle, two distinct and, in class terms, opposing interpretations of the national democratic revolution emerged. What 'two tactics' meant for the South African revolution was about to become clear.

The general history of workers' organisations and trade unions in South Africa is told up to 1950 from the SACP perspective by Simons and Simons (1983). Luckhardt and Wall (1980) provide a comprehensive history of the pro-ANC South African Congress of Trade Unions (SACTU) until the end of the 1970s. At this time there was a resurgence of trade unionism inside South Africa, especially in the Eastern Cape, and with it came a new debate between 'workerists' and ANC 'populists'. Eddie Webster's study of workers' arduous conditions in metal foundries linked changes in the labour process to the radical form of trade unionism that these workers created, based on the role of the shop steward. Webster saw the rise of the shop stewards' movement as 'a challenge from below' (1985: 231 ) and 'the birth of working class politics' (261). Webster worked with the FOSATU federation formed in 1979, the 'workerist' tendency that emphasised rank-and-file trade unionism. Steven Friedman (1987) covered the black trade unions as a journalist, telling the story of the Durban strikes in 1973 and the debate inside the movement about whether to register with the state after the Wiehahn reforms, which FOSATU did, but the SACTU/ANC-aligned unions refused seeing registration as tacit collaboration. The SACTU/ANC 'populist' tradition came forward into a new generation of general unions linked with community-based struggle organisations. Leaders like Moses Mayekiso emerged who embodied both strands.

COSATU was formed in 1985 from the convergence of unions led by the 'workerist' and 'populist' tendencies, and the 180,000 strong National Union of Mineworkers (NUM) that broke away from another federation, CUSA. The independent union movement had swollen from just 10,000 members in 1976 to COSATU's 600,000 members (Naidoo 1986), with 250,000 more in other federations. The first years of COSATU bore great promise of possibilities for united worker resistance, and within its first eight months the federation led the two biggest strikes in South Africa's history. It was mobilising against the immediate challenge of the regime's restrictive Labour Bill, and in a wider sense to bring apartheid to an end. COSATU general secretary, Jay Naidoo, made the point that COSATU was engaged in the general democratic struggle, both as an independent organisation of the working class and an essential component of the democratic forces:

It is clear that in the specific conditions of our country it is inconceivable that political emancipation can be separated from economic emancipation.(Goddard 1986: 10)

COSATU's inaugural congress was a high point, calling for disinvestment and resolving to support all sections of the oppressed:

To call for a national strike should the apartheid regime carry out its threat to repatriate any migrant workers ...

... under capitalist conditions of exploitation unemployment is a reality facing every worker at all times. To establish a national unemployed workers' union as a full affiliate ...

... women workers experience both exploitation as workers and oppression as women and that black women are further discriminated against on the basis of race ...(ibid.)

In terms of strategy, Naidoo asserted: 
We are not fighting for freedom which sees the bulk of workers continuing to suffer as they do today. We therefore see it as our duty to promote working-class politics. A politics where workers' interests are paramount in the struggle. (cited in Goddard 1986: 10)

This was a militant reformulation of the national democratic revolution strategy in terms 'where workers ' interests are paramount' (emphasis added). Meanwhile some distance away, in London in fact, SACP leader Joe Slovo was likewise reformulating the concept of national democratic revolution, but in the opposite direction, onto terms where capitalist interests would be paramount:

For some while after apartheid falls there will undoubtedly be a mixed economy, implying a role for levels of non-monopoly private enterprise represented not only by the small racially oppressed black business sector but also by managers and business people of goodwill who have or are prepared to shed racism. (cited in Reed 1986: 10)

As David Reed pointed out, Slovo was deliberately imprecise, 'his failure to specify that the land and monopoly industry will be expropriated' tailored to assure 'disparate forces' ranging from Anglo American to the British Labour Party that private enterprise would be safe (Reed 1986: 10). This was a retreat from the 1962 programme, whose 'non-capitalist lines' had become capitalist lines; and a long step away indeed from Lenin's "nationalisation of the land is not only the "last word" of the bourgeois revolution, but also a step towards socialism', which in the South African context could only translate into nationalisation of the mines and mineral resources. This, then, was an intended reformulation of the national democratic revolution, into terms where the interests of big capital would remain paramount.

Still, the message was coded. Wolpe's insistence upon contingency in the concept of national democratic revolution (1988: 32) was an adroit supporting move to Slovo; any realistic strategy needed to take into account the unknowns of political struggle. Those more schooled in Marxism might recall that Lenin himself updated his view on how the analytically separable democratic revolution and the socialist revolution were connected in practice. Yet, for all the sophisticated pseudo-theoretical argumentation (Slovo 1988), the SACP's revived version of the 'national democratic revolution' proved to be so elastic that it meant all things and none. It took some time for the realisation to emerge that the SACP's version of 'contingency' in the national democratic revolution meant something altogether different to Lenin's; in fact, it was not contingent at all but its opposite, the enforced separation between ending apartheid and bringing down capitalism. In practice, it was used to cover up not only the ANC's historic compromise, but whatever venal opportunism was attendant upon it (Bond 2000; McKinley 1997;)

\section{Regulation theory in the moment of transition}

Meanwhile, as the endgame of apartheid approached, a particular school of political economy arose temporarily like a fashion. At the end of the 1980s, a group of scholars working with the union federation COSATU developed an analysis of organic crisis in South Africa based on the 'regulation' approach from France. They were to pave the way and give a radical economics gloss to the political turnaround that was about to take place. The approach theorises changes to capital accumulation in any given capitalist society using the inter-related concepts of regime of accumulation, mode of exploitation, and regulation. In this view, regulation is broadly 'the way in which the determinant structure of a society is reproduced' (Aglietta 1980: 13). Applying this to South Africa, Stephen Gelb argued that the post-war accumulation model crystallised by apartheid was best conceived as a 'racial Fordism'. Henry Ford had not only pioneered mass production, but linked this to a society of mass consumption in the US: his workers should earn enough to own one of the cars they produced. Gelb saw a similar accumulation model combining mass production and consumption in South Africa, with the crucial qualification that it was racially structured: wages were limited and consumption was limited, only white workers were paid enough to afford a car. Racial Fordism was necessary to cement the support of the white population, and possible so long as it could be built on the continuing success 
of mining. South Africa has chosen an accumulation strategy that 'made possible the importation of the capital equipment necessary to expand manufacturing' (Gelb 1991: 15).

Contingency is built into the regulation mode of analysis, too, as it seeks to explain why one strategy is adopted rather than another. The 'racial Fordism' strategy relied on the dollar price of gold and other mineral exports to pay for the imports. There was a competition for investment between mining and manufacturing. Their growing demand for skilled but cheap labour led capitalist organisations to press for the colour bar to float, that is to allow some African workers into occupations previously reserved for whites, and into more settled urban living. These were changes that were resisted by the political regime, putting 'racial Fordism' into crisis. In this regard, Gelb noted without irony the convergence of his analysis with the calls for reform by Harry Oppenheimer, inheritor of the Anglo American Corporation (19-20).

Gelb argued the need for an alternative economic strategy in which the 'developmental state' was the central actor that would lead social restructuring to the benefit of the working class. The agency of the state was 'an essential counterweight to the inevitable reluctance of extremely powerful private economic agents, especially the conglomerates, to bring about a fundamental shift in economic development' (31). The strategy the regulationists proposed was a series of industrial-sector plans requiring the co-operation of business and labour under the direction of government. Redirecting finance to invest in state priorities would be a particular challenge given South Africa's 'highly concentrated corporate structure, which dominates the provision of external finance to industrial firms' (31). Behind the apparent pragmatism of the approach was a huge dose of utopianism: wishful thinking that the conglomerates would accept an arrangement in which their profitability would be subordinated to a social justice agenda through state-directed plans for each industry. Bond (2000) and many others point out that in practice the opposite happened: big business controlled the economic policies of the post-apartheid state.

There are weaknesses at the heart of the regulation theory that correspond to its exponents' technocratic tendency. The theory, Gelb argued, 'focuses above all on the process of exploitation in class societies; that is, the appropriation by one class of the surplus produced by another. The various processes through which this surplus is expanded or contracted, comprise the major driving force in the accumulation process' (Gelb 1991: 9). This claim is not substantiated. On the contrary, regulation theorist Aglietta doubts the essentiality of surplus value as a concept (1980: 15), and rejects the concept of imperialism 'as an ambiguous notion' (29). In Gelb's book, none of the sector chapters actually look at the issue of surplus value and exploitation. What emerged from the regulation school's apparent sophistication was actually a watered down version of Marxism. It recognised class struggle, but without relating it to workers' production of surplus value and its conversion into capital, that is with the general law of capital accumulation; it recognised monopoly capital is a social power and yet hung back from its conversion into social property, as we have seen Marx had anticipated.

At the vital moment, these theoreticians bestowed a 'New Left' patina to the SACP/ANC's compromise with capital. But what about the third party in the alliance: the trade unions? Despite being positioned as advisers to COSATU, the crucial political factor that the regulationists ignored was the revolutionary potential of the mass movement, the only actor capable of breaking the power of the banks and conglomerates to enforce their nationalisation. Instead the regulationists advocated a 'developmental state' to counter-weigh big capital. This set them on a trajectory; the trade-union researchers became ANC government advisers and reluctant co-authors of the neo-liberal programme.

\section{From regulation to reconciliation}

The commitment of the political executive is pivotal in the power play between state and capital. By 1991, the ANC had already sufficiently indicated its accommodation with big business to bring into serious doubt its intention of implementing the regulationists' advised alternative strategy. While the tensions within the triple alliance would take several years to eventually play out, the ANC leadership 
was already courting big business. On 4 July 1990, Nelson Mandela addressed British businessmen on the 'critical need' for rapid growth that 'cannot happen without large inflows of foreign capital' (cited in Padaychee 1991: 108). The transition was going to be managed top-down. As Marais puts it:

The ANC's historical privileging of the political over the economic invited a settlement that would allow for significant restructuring of the political sphere, and broad continuity in the economic sphere. (2011: 70)

The lynchpin of the continuity was the arrangement made with a core group of multinationals led by Anglo American, as detailed by Terreblanche (2002) and Marais (2011). The die was fully cast in 1993 when, as part of the power-sharing interim government, the ANC applied secretly for an IMF loan, with the standard conditions attached (Martin 2013: 163). The outcome was a reconciliation with white-owned capital and imperialism that pushed socialism off the agenda (Bond 2013, pp. 575-576).

\section{South Africa after apartheid}

Democratic rule was welcomed, but class divisions have polarised. The unemployment rate actually increased from 28 per cent in 1995 to 42 per cent in 2003, and by 2013 stood at 34 per cent (Di Paola and Pons-Vignon 2013); (Kingdon and Knight 2009). 55 per cent of 23 year olds are not in education, employment or training (Lolwana 2014). 65 per cent of African women are unemployed (Ntlebi 2011) Income distribution is still highly racialised, 'in 2005/06, whites accounted for 9.2 per cent of the population but netted 45 per cent of total household income' (Marais 2011: 209). The African population suffers one of the worst levels of HIV/AIDS and tuberculosis in the world (264). Migrant mine workers still suffer silicosis and other crippling diseases on an industrial scale (McCulloch 2013). Johannesburg is threatened by rising acid mine water, Soweto is still rimmed by poisonous tailings dumps, and communities in the Mpumulanga coalfield are engulfed by a cocktail of pollutants. According to environmental activist Matthews Hlabane "the soil is burning and full of salt, the water is contaminated, the air is dangerous", cited in (Munnik 2008 52).

Black economic empowerment (BEE) has meant business opportunities for some, but it is no more than a minority who have prospered, 'the real beneficiaries of the democratic breakthrough have been the various fractions of the black middle classes, which have seen rapid growth' (von Holdt 2013, 593). South Africa after apartheid has not been a utopian experience for the working-class majority of the black majority. The decision of the ANC to embrace the neo-liberal model has layered a new set of ills over the apartheid legacies of debt, disease, violence, exclusion, poverty, and environmental disaster. Good entry points into the critical literature that grasp the real content of the transition are Marais (2011), Satgar (2102), Terreblanche (2002), and von Holdt (2013).

A critical perspective from within liberal democracy is exemplified by Andrew Feinstein (2009) and R.W. Johnson (2010), who are scandalised by defence minister Joe Modise's corrupt arms deal with a British Aerospace consortium. Their justified exposure of the ANC in power is, however, shorn of any critique of its neo-liberalism. In similar fashion, Plaut and Holden (2012) ask 'Who rules South Africa?', and answer narrowly and only in terms of political parties rather than the socioeconomic structures of class (and race) power. Liberals do not like the ANC's corruption, advancing to degeneracy under Mbeki and Zuma, but they nonetheless back its economic programme. Liberal historian Leonard Thompson's History of South Africa identifies that once reconciliation was achieved the Mandela Government had two major goals: 'to create growth and to improve the quality of life for the majority of citizens', but, he asserts, 'if both goals were pursued simultaneously from the beginning of the new regime, they would not be compatible' (2001: 278). That is, within the liberal paradigm, a challenge to private property relations is even now off the agenda; what is needed to deepen democracy is first and foremost more capitalist economic growth providing the base for a future redistribution of wealth. Recognising growth first, redistribution later was the ANC's 'crash course in reality'. But we have been here before; this is trickle down, the mantra of neo-liberalism 


\section{Neo-liberalism after apartheid}

Vishwas Satgar (2012) provides a critical overview of the post-apartheid period. He draws on neoGramscian, global political economy to question the characterisation of the South African state as a 'developmental state', as it is not pursuing any substantive strategy of state-led industrialisation and redistribution. Satgar sees South Africa as fully aligned with the post-Washington consensus version of neo-liberalism. The state interventions that take place are to facilitate market efficiencies, capital investment, and accumulation. The economic structural roots are to be traced back to the late 1980s and the outward movement of finance capital that continued through the 1990s into the post-apartheid era. Through a series of programmes, the ideology of the ANC as the ruling party has indigenised and given 'an African voice to neoliberalism' (43). Satgar sees the state as no longer managing national capitalism, but transnational capitalism: 'South Africa's mode of production is now driven by an externalised logic' (44). The 'externalised logic' is competitiveness in global markets. ANC Governments have sought to impose the drivers of competitive advantage through trade liberalisation, tight monetary and fiscal policies, and dismantling self-sufficiency. It was in this third dimension that the peculiarities of apartheid's political economy were most strongly present. The legacy included a comprehensive array of parastatal energy corporations across the steel, coal, electricity, and hydrocarbon sectors, as well as arms manufacture and transport infrastructure that in the ANC's initial Reconstruction and Development Programme (RDP) would continue as the crucial hub to endogenous development. The approach was quickly undermined by the adoption in 1996 of the misnamed Growth, Employment and Redistribution (GEAR) framework.

Satgar acknowledges that state programmes provide 14 million people with social grants and have built a million houses, an example of 'post-Washington' poverty alleviation measures; nonetheless, 'underpinning this reality is a state incapable of stemming the tide towards deepening inequality' (54). Many in social movements targeted by the ANC machine might go further to argue that the state is not only incapable but decidedly unwilling.

\section{Post-apartheid into globalization: Global apartheid}

Fine and Rustomjee make an important analysis of South Africa's economy, arguing that the 'minerals energy complex' (MEC) remains at its centre and furthermore plays 'a determining role throughout the rest of the economy' (1996: 5). 'Complex' suggests interconnection and these authors delineate the inputs and outputs that were constructed over decades around three principals: the mining corporations; formerly state, now privatized, state energy corporations; and, at its hub, finance. The complex gives the economy unusual characteristics. Coal is largely exported or turned into gas or electricity, rather than consumed in homes. The South African economy is 'uniquely electricityintensive', with 40 per cent of electrical energy used 'in mining and mineral processing' (8). These authors recognise the continuing central importance of Anglo American and its association with 'South Africa's highly developed financial institutions', and point out that in this system of accumulation, Finance is the epicentre of the complex (91-92). Drawing on O'Meara (1983), Fine and Rustomjee (1996) analyse the process whereby Afrikaner capital emerged in the inter-war period to compete and converge with English capital. They trace the inputs and outputs to the mining and energy complex, note the growth of uranium and platinum mining, and review debates on industrial policy. Bell and Farrell (1997) and Nattrass and Seekings (2011: 549) argue that the MEC interpretation overstates the weight of the minerals energy complex by including all related manufacturing, and understates the extent of diversification of manufacturing sectors.

The restructuring of mining capital and other conglomerates throughout the transition is a vital topic. Cross-sector shifting of investments complicates the picture. In the late 1980s, a lot of foreign corporations, especially US ones, divested from South Africa. Sanctions penned the mining corporations into their domestic capital markets, so they bought into the businesses previously owned 
by foreign capital, for example the automotive industry, as analysed in (Barnes 2013). From its inception in the 1920s, the industry's production combined imported kits with increasing local content. The1980s saw 'South African mining houses and pension funds acquiring the assets of the departing MNCs' (249), a consequence of the pressure of sanctions. By 1993, mining capital dominated vehicle production. The sole exception was Volkswagen, which stayed throughout. The other multinationals returned in the 1990s to form joint ventures with local capital, then further buyouts such that since 2008 all the seven major vehicle manufacturers have been 100 per cent owned by global brand multinationals.

In correlation with these movements has been the 'offshoring' of big mining capital's headquarters as soon as it was able to do so after 1994. Fine and Rustomjee highlight the 'extent of capital flight' $(1996: 11,177)$ that was at first illegal but has since been officially allowed. The phenomena are investigated in a series of studies that probe:

a particular combination of short-term capital inflows (accompanied by rising consumer debt largely spent on luxury items) and a massive long-term outflow of capital as major 'domestic' corporations have chosen offshore listing and to internationalize their operations while concentrating within South Africa on core profitable MEC sectors. (Ashman et al.: 2010: 178)

Capital flight averaged over 9 per cent of GDP from 1994-2000, rising to 12 per cent between 2001 and 2007. Major corporations 'such as Anglo American, De Beers, Old Mutual, South African Breweries, Liberty, Sasol and Billiton' have relisted on the London Stock Exchange (Ashman et al. 2011: 13). The moves are a combination of push and pull factors. Moving out corporate HQs means that dividend payments escape South Africa's exchange controls and removes the corporations from any risk of nationalisation. Moving to London provides security, a better access to credit, and an enhanced platform for global operations. These corporations that were the principal economic beneficiaries of more than a century of racial capitalism have internationalised their operations through London and repositioned themselves as global players.

Ashman and Fine (2013) link the offshoring process with the restructuring of the financial sector in South Africa itself, which by 2010 was dominated by just four conglomerates: Standard Bank, ABSA, First Rand, and Nedbank, which between them control 84 per cent of the market. Two of these 'Big Four' have a London connection. UK-based Barclays Bank bought a controlling share in ABSA in 2005; and Nedbank is controlled by Old Mutual, the insurance conglomerate that moved to London and is 'placed thirtieth of the world's most powerful corporations' (165).

As well as capital flight, relocating the site of capital ownership, there is the distinct question of capital flows into and out of the country. South Africa was 'the single largest investor in FDI projects in Africa outside of South Africa itself in 2012' (Ernst and Young 2013: 5). South Africa is also the destination for more FDI projects than any other African country (31). The top five source countries for FDI projects in Africa from 2007-12 were the US, UK, France, India, and South Africa. China is ninth on the list. The UK had three times more projects. Of the top ten global mining corporations with direct investments in Africa, three (arguably four) are UK-based, and three are South Africa-based (Fig 2014). Each of the UK-based global mining corporations has significant connections with South Africa.

We started this essay with Hilferding, to whom Ashman et al. (2010: 175) wrongly ascribe the idea that industrial and banking capital fuse to form finance capital. As we have seen, his argument is rather that they are 'intimately related' through credit and capital markets, and the form of the linkage is fictitious capital. More generally, there is yet to be a positive connection between theories of imperialism and the particular form of neo-liberalism and capital restructuring in contemporary South Africa.

William Martin (2013) takes a world-systems approach to framing South Africa within international racial hierarchies of core and periphery countries. Like Fine and Rustomjee, he gives special emphasis to the industrialisation that took place in the inter-war period. He looks closely at the 
policies of the Nationalist and Labor Pact Government from 1924 with case studies of railways, banking, and tariffs. The government built a fully national railway system, whose extension and tariffs were geared to the needs of white farmers and white labour rather than the mining magnates. South Africa created its own reserve bank so that monetary policy, specifically decisions to go on and off the gold standard, were not so directly tied to British imperial interest. Similarly, South Africa sought a customs union with its neighbours, on terms that would favour its interests. The state steel corporation ISCOR was constructed in the 1930s to locally supply mines, rail, and incipient manufacturing industries. Martin argues that with these changes South Africa managed to industrialise and emerge as a 'semi-peripheral' state, a relation that has seen major continuity into the post-apartheid period as South Africa continues to export manufactures and capital to its sub-Saharan neighbours. Bond reads this unequal relation as 'aspirant sub-imperialism' (2008: 25).

\section{Social movement struggles and politics}

This essay cannot do justice to the depth and diversity of social struggle movements in post-apartheid neo-liberal South Africa. It is nonetheless essential to appreciate the creative mainspring, the energy of the working class in resistance. Challenging Hegemony collects excellent essays on social movements in peri-urban Johannesburg, the National Land Committee of rural farm dwellers, and the Treatment Action Campaign's patient-led fight for state support and treatment of HIV/AIDS (Gibson 2006).

Ashwin Desai's We are the Poors relays the eruption of community-based class struggles. Community movements have sprung up amongst the poor in Chatsworth near Durban and other townships nationwide, fighting against the effects of neo-liberalism on their lives. The trigger issues are the state's callous determination to drive through market solutions to problems of service provision. Metropolitan councils insist on 'cost recovery', rent debt collection and disconnection for non-payment for water and electricity services. With ever more workers unemployed or at best casually employed, they simply cannot pay. The impoverished find ways to reconnect their homes, to resist evictions, to stand up to ANC local councillors and the police. Drawing on past struggle experiences, but also overcoming old divisions, people in the new movements are taking collective action for their very survival, putting themselves onto the frontline with innovative direct-action tactics. Starting from their immediate need to stop cut-offs and evictions, communities united around the Durban Social Forum, 'New Apartheid: Rich and Poor'. Durban in 2001 was 'the first time a mass of people had mobilized against the ANC government' (2002: 138).

The ANC's neo-liberal programme continues to evoke counter-movements. In the Western Cape, Mandela Park is another community that found itself under armed assault by the state, its leaders either imprisoned or on the run, for resisting mass evictions from privately built housing. The evictions were consequent on the ANC's adoption of a Structural Adjustment Programme in 1996. The company manufacturing the pre-paid water meters is Conlog Holdings, the same corporation that Modise took directorship of as reward for the British Aerospace fighter deal (Pithouse and Desai 2004).

Social movements face considerable problems in finding a way to consolidate an ongoing political project. Trevor Ngwane was an ANC councillor in Johannesburg who refused to implement party policy to privatise domestic services. He was thrown out of the ANC and then stood against them on an anti-privatisation platform. The Anti-Privatisation Forum was formed in 2000 to unite struggles by grass-roots campaigns fighting the electricity cut-offs and the privatisation of workers' jobs at Wits University (Ngwane 2003; Buhlungu 2004). It was from independent social struggles like these, that Ngwane and other socialists began to advocate the formation of an independent workers party, see Bond, Desai and Ngwane (2012). Against this perspective, Buntu Siwisa (2010) recognises the breakdown of social citizenship exemplified by the APF, but disputes that 'intellectuals-cumactivists' have a mandate from the urban poor for forming an electoral alternative to the ANC. 
Another explanation for the difficulty that social movements have is that they are subject to dirty tricks and repression by the ANC at the local level (Zikode 2013). The rural poor, farmworkers, went on strike in 2012 (Jara 2013). The persistence of these social struggles from below is a constant reminder that, despite the difficulties, there is a possibility of a party emerging to the left of the ANC. Several populist pretenders have thrown their hats into the electoral ring, but the more difficult challenge remains of constructing an inclusive and non-hierarchical social and political national movement.

The recovery of the mass movement is ongoing. In the communities, despite ANC-directed state violence against it, the shack dwellers movement Abahlali baseMjondolo continues to resist and 'walk the talk' of advocating socialism from below (Zikode 2013) .

Barchiesi (2011) emphasises the precarious and insecure conditions of the working poor. He encountered 'disorientation, apprehension and disillusionment' (xvii) of municipal workers in Johannesburg and industrial workers in the East Rand. On the demoralisation and decline of collective solidarity in the NUM, see Beresford (2012). There are developments in trade unions across many sectors breaking from the ANC alliance (Amandla! 2013). There is a fight to recover the independence of COSATU from the ANC/SACP; as a result, the now biggest affiliate, the metal workers union, has declared the need for a united front and a new workers party (NUMSA 2013).

In party-political terms, the biggest turnaround has been the emergence of the Economic Freedom Fighters (EFF) under the leadership of Julius Malema, former president of the ANC Youth League. The ANC expelled Malema in February 2012 for fomenting divisions and tarnishing the party's reputation. The criminal charges against him for money laundering and corruption may have been politically motivated, they may be true; either way, Malema's radical discourse has resonated with a growing audience amongst those disillusioned with 20 years of ANC rule. The political issue that got Malema into trouble with the ANC hierarchy was pushing for nationalisation of the mines and the land. Malema visited the striking Marikana miners two days after the Massacre, the first national political figure to do so. He condemned the shootings, attacking the mine's British owners and Cyril Ramaphosa, 'the ANC in government eat with the British' (City Press 2012). Malema returned in October 2013 as the EFF launched itself at a mass rally in Marikana with the slogan 'Economic Freedom in our Lifetime' (Mvoko 2013). The EFF has combined the left wing of the ANC with the Africanist and Black Consciousness traditions, both in its imagery and radical programme (Fogel 2013), and has mounted enough of an electoral challenge to the ANC to take over 6 per cent of the votes, gain 25 seats, and a platform of opposition in the National Assembly (EFF 2014; Sowetan 2014).

\section{Some conclusions}

This essay has looked over a long trajectory of anti-imperialist, anti-apartheid, and anti-capitalist Marxist theories concerning South Africa. I have argued that the anti-apartheid struggle was legitimately conceived as a mass democratic revolution against racism, but I have sought to return content to the notion of national democratic revolution and rescue it from the formulaic and reformist interpretation of the SACP. African nationalism is not inherently reformist; it takes revolutionary directions that can be bolstered by a strategy of unity of the oppressed against all exploitation. The motor of the revolution has been the resistance of the black masses that emerged in the form of the ANC's Congress Alliance and Pan Africanism, reappeared as Black Consciousness, and finally erupted as multifaceted working-class insurrection of sufficient threat to force regime change. The national democratic revolution in South Africa was an alliance of classes as well as races. The impetus of the revolutionary movement was harnessed and channelled by privileged class interests leading the ANC alliance in its crucial phase.

In the fight against apartheid, the ANC had the most successful strategy in that it concentrated on unity in the struggle against apartheid. The strength of being 'anti-apartheid' was, however, turned 
into its opposite: a source of weakness. In abstracting apartheid from its connections with capitalism and imperialism, the ANC has become a vector for the exploitative system. The SACP and ANC's strategy was a bourgeois class project. Black empowerment was for a select few millionaires. The 'us' in the slogan 'South Africa belongs to us!' is not the African masses but a black bourgeoisie that seeks to own and control the post-apartheid democracy as its property.

In the South African context, nationalisation of the mining conglomerates and their transformation into social property would be the last word of the democratic revolution and the first word of the socialist revolution, a measure that great energy was spent to ensure did not happen. This is the connection with socialism, which remains a fight against capitalism and imperialism.

Politically, one chapter has ended and new terms of struggle based on a split from the ANC alliance are being addressed. Questions of how the movement is built, from within or outside the trade unions, from above or below, whether there will be participatory workers' control over social struggles, and the form of political representation of the oppressed are all in contention.

The mission of critical political economy should be to reinforce the efforts of the masses, not to offer up alternative economic policies for the consideration of the bourgeoisie. The system of accumulation of capital wrests on the conversion of surplus value into capital, and must therefore encompass the mode of exploitation of the working class and how this is reproduced systemically. I have argued that the mode of exploitation of the racially oppressed before and during apartheid was a form of super-exploitation. Marikana demonstrates the continuation of super-exploitation in postapartheid class relations. The classical Marxist theories of imperialism that owed so much to material relating South Africa and Britain need to be refreshed in the light of this experience.

Most of the writers cited in this survey, including the present author, are white males and academics, many based in the global North. Allow then a penultimate comment on the diluting effects on theory that is mediated through layers of social privilege. Critical political economy can only make a step forward if it embraces theories and perspectives that originate in working-class experiences in the global South. So informed, it can help illuminate the fundamental continuities of racially oppressive class exploitation, and investigate super-exploitation in South Africa today. Yet the outright rejection of dependency theory by still influential authors (Callinicos 1994; Fine and Harris 1979; Legassick 1976) is holding back the revolutionary contribution of Marxism. To avoid recognition of the greater exploitation of workers in the global South is as incorrect theoretically as it is unedifying morally; above all, it is misleading politically as to the principal agency of revolutionary change, that will come from the oppressed. I have argued that a generation ago, such evasion of superexploitation missed the essence of apartheid in South Africa; today it misses the essence of global apartheid.

Cabral's and Fanon's thesis has been realised in the negative in South Africa. The paradox of post-apartheid has been that so long as the masses trusted the ANC, any substantive alternative strategy would be politically inoperable. The Marikana Massacre changed that. Although the ideological spell has been broken, the deal that the ANC and its allies struck means that the legacies of racial capitalism are still being reproduced. The profits that flow into South African corporations from across Africa, and simultaneously flow out from its workers to the global centres of financial power, indicate that post-apartheid has descended into a particular set of neo-colonial relations of collaboration, a neo-colonialism of a special type.

Azania is still on the way. The full potential of the African masses is yet to be realised, but they are once again finding the way forward.

\section{References}

Aglietta, Michel (1980) A Theory of Capitalist Regulation: the US Experience (London: New Left Books). 
Alexander, Neville (1979) One Azania One Nation: The National Question in South Africa (London: Zed Press), http://www.sahistory.org.za/archive/one-azania-one-nation-neville-alexander (accessed 19th March 2015).

Alexander, Neville (2003) An Ordinary Country: Issues in Transition from Apartheid to Democracy in South Africa (New York/Oxford: Berghahn Books).

Alexander, Neville (2010) South Africa: An Unfinished Revolution? http://links.org.au/node/1693 (accessed 19th March 2015).

Alexander, Peter, Thapelo Lekgowa, Botsang Mmope, Luke Sinwell and Bongani Xezwi (2012) Marikana: A View from the Mountain and a Case to Answer (Auckland Park, SA: Jacana Media).

Ally, Russell (1994) Gold and Empire: The Bank of England and South Africa's Gold Producers 1886-1926 (Johannesburg: Witwatersrand University Press).

Amandla! (2013) 'COSATU at the crossroads', Amandla! No. 30 April/May: 12-22

ANC (1955) The Freedom Charter, http://www.anc.org.za/show.php?id=72 (accessed 19 ${ }^{\text {th }}$ March 2015).

Anderson, Kevin (1995) Lenin, Hegel and Western Marxism: A Critical Study (Urbana and Chicago: University of Illinois Press).

Ashman, Sam and Ben Fine (2013) 'Neo-liberalism, varieties of capitalism, and the shifting contours of South Africa's financial system', Transformation 81-82: 144-178.

Ashman, Sam, Ben Fine, and Susan Newman (2010) 'The Crisis in South Africa: Neoliberalism, financialization and uneven and combined development', Socialist Register 47: 174-195.

Ashman, Sam, Ben Fine, and Susan Newman (2011) 'Amnesty international? The nature, scale and impact of capital flight from South Africa', Journal of Southern African Studies, 37(1): 7-25.

Barchiesi, Franco (2011) Precarious Liberation: Workers, the State, and Contested Social Citizenship (Durban: University of KwaZulu-Natal Press).

Barnes, Julian (2013) 'Capital structure of the South African automotive industry: Historical perspectives and development implications', Transformation: Critical Perspectives on Southern Africa, 81/82: 236-259.

Bell, Trevor and Farrell, Greg (1997) 'The minerals-energy complex and South African industrialisation', Development Southern Africa, 14 (4): 591-613

Beresford, Alexander (2012) 'Organised labour and the politics of class formation in post-apartheid South Africa', Review of African Political Economy, 39 (134): 569-589.

Biko, Steve Bantu (2002 [1978]) I Write What I Like: Selected Writings of Steve Biko 1946-77 (Chicago/ London: University of Chicago Press/ Heinemann).

Bond, Patrick (2000) Elite Transition: From Apartheid to Neoliberalism in South Africa (London: Pluto Press).

Bond, Patrick (2008) 'South Africa’s “Developmental State” Distraction', Mediations, 24(1): 9-28.

Bond, Patrick (2013) 'Debt, uneven development and capitalist crisis in South Africa: From Moody's macroeconomic monitoring to Marikana microfinance mashonisas', Third World Quarterly, 34(4): 569-592.

Bond, Patrick, Ashwyn Desai, and Trevor Ngwane (2012) Uneven and Combined Marxism within South Africa's Urban Social Movements, http://amandla.org.za/uneven-and-combinedmarxism-within-south-africas-urban-social-movements-by-patrick-bond-ashwin-desai-andtrevor-ngwane/ (accessed 19 ${ }^{\text {th }}$ March 2015). 
Brickley, Carol (2005) 'Anti-apartheid: A study in opportunism', Fight Racism! Fight Imperialism! 183 (February/March)

http://www.revolutionarycommunist.org/reviews/270-anti-apartheid-a-study-in-opportunism-frfi-183feb-mar-2005.html (accessed 19th March 2015)

Brickley, Carol (2012) 'Writing on the wall for the South African "national democratic revolution"', Fight Racism! Fight Imperialism! 229 (October/November):

http://www.revolutionarycommunist.org/international/2718-writing-on-the-wall-for-the-south-africannational-democratic-revolution (accessed 19th March 2015)

Brickley, Carol, Terry O'Halloran, and David Reed (1985) South Africa - Britain Out of Apartheid; Apartheid Out of Britain! (London: Larkin Publications).

Brockway, Lord Fenner (1975) 'Uranium purchases from Namibia', in House of Lords Debate, 20 October 1975, vol. 364 cc1226-12234 (London: Hansard), http://hansard.millbanksystems.com/lords/1975/oct/20/uranium-purchases-from-namibia (accessed 19th March 2015).

Brown, Gavin and Helen Yaffe (2014) 'Practices of solidarity: Opposing apartheid in the centre of London', Antipode, 46(1): 34-52.

Buhlungu, Sakhela (2004) The Anti-Privatisation Forum: A Profile of a Post-Apartheid Social Movement (Durban SA: University of KwaZulu-Natal)

Bunting, Brian (1964) The Rise of the South African Reich (London: Penguin).

Cabral, Amilcar (1966) The Weapon of Theory, http://www.marxists.org/subject/africa/cabral/1966/weapon-theory.htm (accessed 19 ${ }^{\text {th }}$ March 2015).

Cabral, Amilcar (1989) Unity and Struggle: Speeches and Writings of Amilcar Cabral (New York: Monthly Review Press).

Callinicos, Alex (1988) South Africa between Reform and Revolution (London: Bookmarks).

Callinicos, Alex (1994) 'Marxism and Imperialism Today' in Alex Callinicos, John Rees, Chris Harman, and Mike Haynes (1994) Marxism and the New Imperialism (London: Bookmarks), pp. 11-66.

Callinicos, Luli (1981) A People's History of South Africa Volume 1. Gold and Workers 1886-1924. (Johannesburg: Ravan Press).

City Press (2012) 'They killed you because Cyril has stake', City Press Online, 20 August, http://www.youtube.com/watch? $\mathrm{v}=3$ SEOtc9kaCw $\left(\right.$ accessed $19^{\text {th }}$ March 2015).

Commonwealth Committee (1989) South Africa: The Sanctions Report (London: James Currey/ Penguin).

Davies, Robert (1979) Capital, State, and White Labour in South Africa, 1 1900-1960: an Historical Materialist Analysis of Class Formation and Class Relations (Atlantic Highlands, NJ.: Humanities Press).

Davies, Robert, Dan O'Meara, and Sipho Dlamini (1984a) The Struggle for South Africa: A Reference Guide to Movements, Organizations and Institutions. Volume One (London: Zed Books).

Davies, Robert, Dan O'Meara, and Sipho Dlamini (1984b) The Struggle for South Africa: A Reference Guide to Movements, Organizations and Institutions. Volume Two (London: Zed Books). 
Desai, Ashwin (2002) We are the Poors: Community Struggles in Post-Apartheid South Africa (New York: Monthly Review Press).

Di Paola, Miriam and Nicolas Pons-Vignon (2013) 'Labour market restructuring in South Africa: Low wages, high insecurity', Review of African Political Economy, 40(138) December: 628-638.

ECCI (Executive Committee of the Communist International) (1928) The South Africa Question https://www.marxists.org/history/international/comintern/sections/sacp/1928/comintern.htm (accessed 19th March 2015)

EFF (Economic Freedom Fighters) (2014) EFF Elections Manifesto, http://effighters.org.za/wpcontent/uploads/2014/02/EFF-ELECTIONS-MANIFESTO.pdf (accessed 19 ${ }^{\text {th }}$ March 2015).

Ernst and Young (2013) Africa Attractiveness Survey http://www.ey.com/Publication/vwLUAssets/Africa_Attract_2013_Getting_down_to_business/\$FILE/Africa_attractiveness_2013_web.pdf (accessed $19^{\text {th }}$ March 2015).

Fanon, Frantz (2000 [1963]) The Wretched of the Earth (New York: Grove Press).

Feinstein, Charles H. (2005) An Economic History of South Africa: Conquest, Domination, Development (Cambridge: Cambridge University Press).

Feinstein, Andrew (2009) After the Party: Corruption, the ANC and South Africa's Uncertain Future (London/New York: Verso).

Fieldhouse, Roger (2005) Anti-Apartheid: A history of the movement in Britain - A study in pressure group politics (London: Merlin)

Fig, David (2014) State of Extraction: the New Scramble for Africa, Transnational Institute, http://www.tni.org/sites/www.tni.org/files/download/state of extraction chapter.pdf (accessed 19th March 2015).

Fine, Ben (2010) 'Engaging the MEC or a few of my views on a few things', Transformation: Critical Perspectives on Southern Africa, 71: 26-49.

Fine, Ben (2012) 'Assessing South Africa's new growth path: framework for change?', Review of African Political Economy, 39(134): 551-568.

Fine, Ben and Laurence Harris (1979) Rereading Capital (London: Macmillan).

Fine, Ben and Zav Rustomjee (1996) South Africa 's Political Economy (Johannesburg: University of the Witwatersrand Press).

First, Ruth; Jonathan Steele and Christabel Gurney (1973) The South African Connection: Western Investment in Apartheid (London: Penguin).

Fogel, Benjamin (2013) 'The EFF and the Left', Amandla! 32 (November): 46-47

Friedman, Steven (1987) Building Tomorrow Today: African Workers in Trade Unions 1970-1984 (Johannesburg: Ravan Press).

Gelb, Stephen (1991) 'South Africa's economic crisis: an overview' in Stephen Gelb (ed.) South Africa's Economic Crisis (Cape Town/London: David Philip/Zed Books): pp.1-32

Gibson, Nigel (2006) Challenging Hegemony: Social Movements and the Quest for a New Humanism in Post-Apartheid South Africa (Trenton NJ/Asmara, Eritrea: Africa Research \& Publications).

Goddard, Andy (1986) 'COSATU: New weapon against apartheid', Fight Racism! Fight Imperialism! 61 (August): 10

Good, Dorcas and Michael Williams (1976) South Africa: The Crisis in Britain and the Apartheid Economy (London: Anti-Apartheid Movement). 
Guillén, Arturo (2013) 'Financialization and financial profit', paper presented at the Fourth Annual Conference on Political Economy Activism and Alternative Economic Strategies, IIPPE, The Hague, Netherlands, 9-11 July.

Hain, Peter (1971) Don't Play With Apartheid: The Background To the Stop the Seventy Tour Campaign (London: Allen \& Unwin).

Hanlon, Joseph (1986) Apartheid's Second Front: South Africa's War Against its Neighbours (London: Penguin).

Higginbottom, Andy (2011) 'Gold mining in South Africa reconsidered: New mode of exploitation, theories of imperialism and capital', Économies et Sociétés, 45(2): 261-288.

Hilferding, Rudolf (1981 [1910]) Finance Capital: A Study of the Latest Phase of Capitalist Development. London: Routledge.

Hirson, Baruch (1992) 'Colonialism of a Special Type and the Permanent Revolution', in Searchlight South Africa, 2(4) January: 48-55.

Hobson, J.A. (1900) The War in South Africa: Its Causes and Effects (London: James Nisbet).

Hobson, J.A. (1988 [1902]) Imperialism: A Study, 3rd edn (London: Unwin Hyman).

IDAF (1983) Apartheid: The Facts (London: International Defense and Aid Fund for Southern Africa).

Innes, Duncan (1984) Anglo American and the Rise of Modern South Africa (London: Heinemann Educational Books Ltd).

Jara, Mazibuko K. (2013) 'Neoliberal land \& agricultural policies at heart of farm strikes', Amandla! 28/29 (January): 18-19

Johnson, R.W. (2010) South Africa's Brave New World: The Beloved Country Since the End of Apartheid (London: Penguin).

Johnstone, Frederick (1976) Class, Race and Gold: A Study of Class Relations and Racial Discrimination in South Africa (London: Routledge and Kegan Paul).

Johnstone, Frederick (1982) "Most Painful to Our Hearts": South Africa through the Eyes of the New School', Canadian Journal of African Studies/Revue Canadienne des Études Africaines, 16(1): $5-26$.

Kingdon, Geeta and John Knight (2009) 'Unemployment: South Africa's Achilles' Heel' in Aron, Janine, Brian Kahn and Geeta Kingdon (eds) South African Economic Policy Under Democracy (Oxford: Oxford University Press): pp 300-326)

Lanning, Greg with Marti Mueller (1979) Africa Undermined: Mining Companies and the Underdevelopment of Africa (London: Penguin).

Latimer, Amanda (2014) 'Superexploitation, the Race to the Bottom and the Missing International', in S.M. Bâ and Immanuel Ness (eds) The Palgrave Encyclopedia of Imperialism and AntiImperialism (New York: Palgrave Macmillan).

Legassick, Martin (1974) 'South Africa: Capital accumulation and violence', Economy and Society 3: 253-291.

Legassick, Martin (1976) 'Perspectives on African “underdevelopment"', Journal of African History, 7(3): 435-440.

Legassick, Martin and Duncan Innes (1977) 'Capital restructuring and apartheid: A critique of constructive engagement', African Affairs 76: 437-482. 
Lenin, V.I. (1905) Two Tactics of Social-Democracy in the Democratic Revolution, http://www.marxists.org/archive/lenin/works/1905/tactics/ (accessed 19th March 2015).

Lenin, V. I. (1907) The Agrarian Program of Social-Democracy in the First Russian Revolution of 1905-1907, http://www.marxists.org/archive/lenin/works/1907/agrprogr/index.htm (accessed Accessed 19th March 2015).

Lenin, V.I. (1916a) Imperialism: The Highest Stage of Capitalism,

http://www.marxists.org/archive/lenin/works/1916/imp-hsc/ (accessed 19 ${ }^{\text {th }}$ March 2015).

Lenin, V.I. (1916b) Imperialism and the Split in Socialism, http://www.marxists.org/archive/lenin/works/1916/oct/x01.htm (accessed 19th March 2015).

Lenin, V.I. (1917) Postscript to The Agrarian Programme of Social-Democracy in the First Russian Revolution, 1905-1907.

http://www.marxists.org/archive/lenin/works/1917/agrprogr/postscr.htm (accessed 19th March 2015).

Lenin, V.I. (1920) Report of the Commission on the National and the Colonial Questions, http://www.marxists.org/archive/lenin/works/1920/jul/x03.htm\#fw3 (accessed $19^{\text {th }}$ March 2015).

Lipton, Merle (1979) 'The debate about South Africa: Neo-Marxists and Neo- Liberals', African Affairs 78: 57-80.

Lipton, Merle (1986) Capitalism and Apartheid: South Africa 1901-1986, 2nd edn. Aldershot: Wildwood House.

Lodge, Tom (1983) Black Politics in South Africa since 1945 (London and New York: Longman).

Lolwana, Peliwe (2014) South Africa Country Report Northern Research Review and Advisory Group (NORRAG)

www.norrag.org/fileadmin/Other_publications/South_Africa_Country_Report.pdf (accessed 26 March 2015)

Luckhardt, Ken and Brenda Wall (1980) Organize ... or Starve! The History of the South African Congress of Trade Unions (London: Lawrence and Wishart).

Luxemburg, Rosa (2003 [1913]) The Accumulation of Capital (London and New York: Routledge Classics).

McCulloch, Jock (2013) South Africa's Gold Mines and the Politics of Silicosis (Auckland Park, SA: Jacana Media).

McKinley, Dale (1997) The ANC and the Liberation Struggle: A Critical Political Biography (London: Pluto Press).

Magubane, Bernard (1979) The Political Economy of Race and Class in South Africa (New York and London: Monthly Review Press).

Mamdani, Mahmood (1996) Citizen and Subject: Contemporary Africa and the Legacy of Late Colonialism (Princeton, NJ: Princeton University Press).

Mandela, Nelson Rolihlahla (1994) Long Walk To Freedom: The Autobiography of Nelson Mandela (London: Abacus).

Marais, Hein (2011), South Africa Pushed to the Limit: The Political Economy of Change (Claremont/London and New York: UCT Press/Zed Press).

Martin, William G. (2013) South Africa and the World Economy: Remaking Race, State, and Region (Rochester NY: University of Rochester Press). 
Marx, Karl (1976 [1867]) Capital Volume 1 (London: Penguin).

Marx, Karl (1981[1895]) Capital Volume 3 (London: Penguin).

Meli, Francis (1988) A History of the ANC: South Africa Belongs to Us (Harare: Zimbabwe Publishing House).

Moorsom, Richard (1982) 'In the grip of imperialism', in Brian Wood (ed.) Namibia 1884-1984: Readings on Namibia's History and Society (London/Lusaka: Namibia Support/United Nations Institute for Namibia).

Munnik, Victor (2008) 'South Africa' in Short, Rebecca The True Cost of Coal (Amsterdam: Greenpeace); pp 48-53 http://www.greenpeace.org/international/en/publications/reports/cost-of-coal/ (accessed $19^{\text {th }}$ March 2015)

Murray, Martin (1987) South Africa: Time of Agony, Time of Destiny (London/New York: Verso).

Mvoko, Vuyo (2013) 'Vuyo Mvoko unpacks the official launch of EFF', sabcdigitalnews (13 October), http://www.youtube.com/watch? $\mathrm{v}=\mathrm{c}$ 1xjvTpB2I (accessed $19^{\text {th }}$ March 2015).

Naidoo, Jay (1986) 'The Significance of COSATU', South Africa Labour Bulletin. 11(5) April-May: $33-39$.

Nattrass, Nicoli and Jeremy Seekings (2011) 'The economy and poverty in the twentieth century' in Robert Mager Ross, Anne Kelk, and Nasson, Bill (eds) (2011) The Cambridge History of South Africa. Volume 2 (Cambridge: Cambridge University Press).

Ngwane, Trevor (2003) ‘Sparks In The Township’ New Left Review 22 (July-August) :37-56

Nkrumah, Kwame (2002 [1965]) Neo-Colonialism: The Last Stage of Imperialism Bedford: Panaf Books

Ntlebi, Ziyanda (2011) 'Factors that influence women's employment Status in South Africa' Int. Statistical Inst.: Proc. 58th World Statistical Congress, 2011, Dublin (Session CPS061) http://2011.isiproceedings.org/papers/951017.pdf (accessed 26 March 2015)

NUMSA (2013) Special National Congress December 17 to 20, 2013 Declaration, at http://www.numsa.org.za/wp-content/uploads/2013/12/SNC-Declaration-final-copy.pdf (accessed 19th March 2015)

O'Meara, Dan (1983) Volkscapitalisme: Class, capital and ideology in the development of Afrikaner nationalism, 1934-1948 (Johannesburg: Ravan Press).

Orkin, Mark (ed.) (1989) Sanctions against Apartheid (Cape Town and Johannesburg/London: David Philip/CIIR).

Ovenden, Keith and Tony Cole (1989) Apartheid and International Finance: A Programme for Change (London: Penguin).

Padayachee, Vishnu (1991) 'The politics of South Africa's international financial relations, 19701990' in Stephen Gelb (editor) South Africa's Economic Crisis (Cape Town/London: David Philip/Zed Books).

Pithouse, Richard and Ashwin Desai (2004) “'But We Were Thousands': Dispossession, Resistance, Repossession and Repression in Mandela Park' Journal of Asian and African Studies 39(4): 239-269

Platzky, Laurine and Cherryl Walker (1985) The Surplus People: Forced Removals in South Africa Johannesburg: Ravan Press.

Plaut, Martin and Paul Holden (2012) Who Rules South Africa? (London: Biteback Publishing). 
Pogrund, Benjamin (1990) How Can Man Die Better... Sobukwe and Apartheid (Cape Town and Johannesburg: Peter Halban Publishers).

Price, Robert M. (1991) The Apartheid State in Crisis: Political Transformation in South Africa 1975-1990 (New York/Oxford: Oxford University Press).

Reed, David (1986) 'Communists and the Revolution South Africa', Fight Racism! Fight Imperialism! 62 (September): 10-11

Roy, M.N. (1922) India in Transition, http://www.archive.org/details/indiaintransitio00roymrich (accessed 19th March 2015)

SACP (1962) The Road to South African Freedom, South African Communist Party, http://amadlandawonye.wikispaces.com $/ 1962 \% 2 \mathrm{C}+\mathrm{SACP} \% 2 \mathrm{C}+\mathrm{The}+\mathrm{Road}+$ to $+\mathrm{South}+\mathrm{African}$ + Freedom (accessed $19^{\text {th }}$ March 2015).

Satgar, Vishwas (2012) 'Beyond Marikana: The Post-Apartheid South African State', Africa Spectrum (2-3): 33-62.

Saul, John (1986) 'South Africa: The question of strategy', New Left Review 60: 3-22.

Saul, John (2012) 'The transition in South Africa: choice, fate ... or recolonisation?' Critical Arts:

South-North Cultural and Media Studies 26 (4): 588-609

Simons, Jack and Ray Simons (1983) Class and Colour in South Africa 1850-1950. London:

International Defence and Aid Fund for Southern Africa.

Siwisa, Buntu (2010) 'Social Citizenship and the Emergence of the New Social Movements in PostApartheid South Africa', in Bill Freund and Harald Witt (eds) Development Dilemmas in PostApartheid South Africa (Scottsville, South Africa: University KwaZulu Press).

Slovo, Joe (1988) The South African Working Class and the National Democratic Revolution (London and Lusaka: Inkululeko Publications).

Sobukwe, Robert Mangaliso (1959) Inaugural Speech, April 1959,

http://www.sahistory.org.za/archive/robert-sobukwe-inaugural-speech-april-1959 (accessed 19th March 2015).

Southall, Roger and Henning Melber (2009) 'Conclusion: Towards a Response' in Roger Southall and Henning Melber (eds) A New Scramble for Africa? Imperialism, Investment and Development (Scottsville SA: University of KwaZulu-Natal Press).; 405-427

Sowetan (2014) 'Thirteen parties won seats in the National Assembly' 10 May 2014 at

http://www.sowetanlive.co.za/news/2014/05/10/25-seats-in-parliament-for-eff-2-seats-for-agang (accessed 19th March 2015)

Terreblanche, Sampie (2002) A History of Inequality in South Africa 1652-2002 (Durban, SA: University of Natal Press).

Thompson, Leonard (2001) A History of South Africa, 3rd edn (New Haven, NJ/London: Yale University Press).

Thörn, Håkan (2006) Anti-Apartheid and the Emergence of a Global Civil Society (New York: Palgrave McMillan).

Trotsky, Leon (1906) Results and Prospects, http://www.marxists.org/archive/trotsky/1931/tpr/ (accessed 19 ${ }^{\text {th }}$ March 2015). 
von Holdt, Karl (2013) 'South Africa: the transition to violent democracy', Review of African Political Economy, 40(138): 589-604.

Webster, Eddie (1985) Cast in a Racial Mould: Labour Process and Trade Unionism in the Foundries (Johannesburg : Ravan Press).

Williams, Michael (1975) 'An analysis of South African capitalism - Neo-Ricardianism or Marxism?' Bulletin of the Conference of Socialist Economists, 4(1): 1-38

Wilson, Francis (1972) Labour in the South African Gold Mines (Cambridge: Cambridge University Press).

Wolpe, Harold (1972) 'Capitalism and cheap labour-power in South Africa: From segregation to apartheid', Economy and Society, 1(4): 425-456.

Wolpe, Harold (1988) Race, Class and the Apartheid State, Unesco/ Organisation of African Unity/James Currey: Paris/Addis Adaba/London.

Yaffe, David (1976) 'South Africa: International Solidarity and the British Working Class', Revolutionary Communist, 5: 56-63.

Zikode, S'bu (2013) 'Despite the state's violence, our fight to escape the mud and fire of South Africa's slums will continue', The Guardian (11 November). 